\title{
Vaginal Lubricant
}

National Cancer Institute

\section{Source}

National Cancer Institute. Vaginal Lubricant. NCI Thesaurus. Code C29170.

Avaginal lubricantcontaining a mixture of polyethylene glycols, glycerol and caprylic/capric triglyceride used to relieve discomfort due to vaginal dryness when applied intravaginally. 